\title{
Equality and Love at the End of The Marriage of Figaro: Forging Democratic Emotions
}

\author{
Martha C. Nussbaum ${ }^{1}$ \\ For a conference in memory of Robert Solomon, The University of Texas at Austin
}

I have no idea what those two Italian ladies were singing about. Truth is, I don't want to know. Some things are better left unsaid. l'd like to think they were singing about something so beautiful, it can't be expressed in words, and it makes your heart ache because of it..., and for the briefest of moments, every last man in Shawshank felt free.

Morgan Freeman ("Red"), in The Shawshank Redemption, of the "Canzonetta sull'aria" from Act III of The Marriage of Figaro

My great peace woman has only a single name: she is called universal justice, humaneness, active reason...Her function, in accordance with her name and her nature, is to inculcate dispositions of peace.

Johann Gottfried Herder, Letters for the Advancement of Humanity (1793-7)

\section{I. "Happy in that way"}

The ancien regime sings in a loud and authoritarian voice, saying, "No, no, no, no, no, no." So, just before the end of Mozart's opera, the Count, as yet secure in his status, rejects the urgings of the other characters to mercy and sympathy, as they kneel, one by one, before him. To Almaviva, revenge for insulted honor is

1 Ernst Freund Distinguished Service Professor of Law and Ethics, Law, Philosophy, and Divinity, The University of Chicago. For comments on an earlier draft, I am grateful to Douglas Baird, Daniel Brudney, Jeffrey Israel, Charles Nussbaum, and Cass Sunstein. 
all-important ("the only thing that consoles my heart and makes me rejoice"2). To display kindness to the imploring, as they humbly kneel, is a noble prerogative, not a general human virtue. He can give it, or he can withhold it. If he chooses the latter course, putting slighted honor ahead of generous condescension, nobody can say he is wrong. That's how the ancien regime operates, animated by a morality of status, shame, and kingly prerogative.

But suddenly the Countess, removing her disguise as Susanna, reveals herself - revealing, at the same time, the stratagem that has trapped her husband in both error and hypocrisy. (Having boasted of ending the droit du seigneur, he has all the while been scheming to enjoy it.) Everyone present exclaims in hushed voices that they don't know what is going to happen next: "Oh heavens, what do I see! Madness! A hallucination! I don't know what to believe!" The strings, coursing up and down, with rapid modulations, express immense agitation and uncertainty. In retrospect, it is the uncertainty of transition between two political regimes.

And now the Count, kneeling before the Countess, sings -- in a voice newly softened by confusion -- a phrase of a type, lyrical and legato, hushed, almost gentle -- that we have never heard from this man before: "Excuse me, Countess, excuse me, excuse me." There is a long pause. ${ }^{3}$

The Countess then sings softly out of the silence: "I am nicer, and I say yes" (più docile io sono, e dico di si). ${ }^{4}$ The musical phrase arcs gently upward, and then bends down as if, almost, to touch the kneeling husband. And now, in hushed and solemn tones, the entire assembled company repeats the Countess's phrase, this time to the words, "Ah, all of us will be happy in that way" (tutti contenti saremo cosi). The choral version of the phrase is reminiscent of the solemn simplicity of a Bach chorale (which, in this Catholic musical universe, denotes a sudden absence of hierarchy). ${ }^{5} \mathrm{~A}$ hesitant orchestral interlude follows.

2 "Già la speranza sola/Delle vendette mie/Quest'anima consola,/E giubilar mì fa," the end of his third-act Aria. Throughout I rely on the edition of the libretto in Mozart 1993.

3 The length of the pause is interpreted variously by different conductors, but both Solti and Karajan hold it for 4 seconds, which feels very long. In the score, the pause is designated by a quarter-note rest with a fermata. (See Mozart 1979, 422).

4 Docile is difficult to translate: one could also say "gentler," or "kinder." I've chosen "nicer," in order to convey the fact that this is a very everyday word, not an exalted moral or philosophical one.

5 For similar observations about Mahler's use of Bach in the Second Symphony, see M. Nussbaum 2001, chapter 15. Here I am alluding to a central theme in the work of Michael P. Steinberg (2004; 2007), who has drawn attention to the many ways in which the period's religious tensions are worked out in its musical culture, in such a way that Protestant and Jew are frequently aligned together in a repudiation of a Catholic culture of representation, "idolatry," and hierarchy. Here, we needn't think of J. S. Bach in particular, since his music was rediscovered only later; the allusion is to the general culture of the Protestant chorale. 
The group now bursts out, a sudden eruption of dizzy elation: ${ }^{6}$ "This day of torment, of craziness, of foolishness - only love can make it end in happiness and joy." Love, it seems, is the key not only to the personal happiness of the central characters, but to the happiness of "all", of the whole community, as they sing: "Let us all rush off to celebrate" (corriam tutti a festeggiar).

The usual story about Mozart's Le Nozze di Figaro (1786) is that it is a copout. Taking the radical Beaumarchais drama of 1778 , whose essential point and emphasis is political, a denunciation of the ancien regime and the hierarchies it imposes, Mozart and his librettist Lorenzo Da Ponte have fashioned an innocuous drama of personal love, defanging the text by omitting, for example, Figaro's long fifth-act monologue denouncing feudal hierarchy and substituting a more extensive treatment of women and their private desires. The Beaumarchais play, which is usually understood to be a major harbinger of the French Revolution, was refused production for many years, and even in 1784, when it was allowed production in France, becoming wildly popular, it remained controversial ${ }^{7}$. Mozart and Da Ponte, by contrast, decided (so the story goes) to escape controversy. The relatively progressive Joseph II had forbidden the Beaumarchais play to be performed in theatres within his realm. Da Ponte, however, persuaded the Emperor that an acceptable opera could be written on the basis of the play. In the process, however, says the received story, ${ }^{8}$ he and Mozart, despite producing a wonderful love-drama, sold out the radicalism of the original.

I shall argue, by contrast, that the opera is as political and as radical as the play, and more deeply so: for it investigates the human sentiments that are the necessary foundation for a public culture of liberty, equality, and fraternity. This construction of sentiment is accomplished more clearly in Mozart's music than in the libretto, so making my argument will require going into considerable musical detail. I shall argue that Mozart agrees (in effect) ${ }^{9}$ with Rousseau in understanding that a political culture requires a new shaping of human attitudes in the realm of love, but that he disagrees with Rousseau about the specific shape of the new attitudes. Whereas Rousseau emphasizes the need for civic homogeneity and solidarity, a patriotic love based on manly honor and the willingness to die for the nation, Mozart envisages the new public love as something gentler, more reciprocal, more feminine - "nicer," to use the Countess's everyday word -- connected more to

6 At this point the key changes from $\mathrm{G}$ major to $\mathrm{D}$ major, and the tempo is marked Allegro assai.

7 For the Beaumarchais play, I use the edition by Malcolm Cook (1992).

8 The received story has some foundation in Da Ponte's Memoirs, which do at least tell us of what he said to try to persuade Joseph II. That hardly shows that the libretto's real intent was apolitical, however; and even if Da Ponte's intent had been utterly apolitical, that would hardly show us that the music that animates the libretto is apolitical.

9 I see no reason to suppose that Mozart read Rousseau, but these ideas about civic sentiment were all around in the 1780's. 
Cherubino's horror of warlike exploits than to Rousseauesque ideas of valor. In the process, Mozart also eschews Rousseauian homogeneity, emphasizing that the new fraternity must protect spaces for the free play of mischief, craziness, humor, and individuality - all of which are connected, in the opera, to the women's world.

In arguing that the culture of the Enlightenment requires a new form of subjectivity, one that the music of this period explores and in part creates, I am agreeing with the central thesis of Michael P. Steinberg's important Listening to Reason, and with the general direction of his interpretation of the opera. I shall argue, however, that Steinberg's more or less total neglect of the politics of gender in Figaro means that he cannot offer us a deep or precise enough account of what needs to change if the revolution is to be humanly possible. Symptomatic of the difficulty in Steinberg's reading (which also neglects the Countess and her "yes") is its total neglect of the male/female character Cherubino (a teenage boy sung by an adult woman); but Cherubino, I shall argue, is in many ways the opera's pivotal character, a male who can be both delightful and loving, capable of empathy and reciprocity, only because he has been educated by women and by music, and thus has grown to love jokes instead of put-downs, singing rather than marching, mischief rather than revenge.

Pursuing such connections between music and emotion, and between both of these and political thought, seems an appropriate way to honor the career of Robert Solomon, whose bold defense of a then unpopular view concerning the cognitive content of emotions opened that field to all those of us who see emotions as rich and multi-layered, rather than as simple pushes and pulls. Indeed, Solomon's work was a major part of what made an inquiry like this one -- which links emotions to political thought not only by seeing them as motivations for action but also, and especially, by showing how they supply political thought with part of its content -- seem potentially fruitful, rather than absurd. The work I have already done on emotions in music, developed in chapters 5 and 15 of Upheavals of Thought (which provides a basis for my arguments here) could not have been begun without the stimulus of Bob's thought and the courage of his example. I hope this essay does at least a little justice to the wonderful career so prematurely and tragically interrupted. I also hope to honor the life of teamwork between Bob and Kathy, which so often focused on the intersection of music and love. ${ }^{10}$

The project will also have the advantage of allowing me to engage in detail with two recent works that I greatly admire: Charles Nussbaum's The Musical Representation (2007), which has done so much to enhance our understanding of musical listening as a mental phenomenon; and Michael Steinberg's Listening

10 I shall later discuss Kathleen M. Higgins (1991); for the collaboration, see especially Robert Solomon and Kathleen Higgins (1991). 
to Reason (2004), which impressively pioneered the enterprise of locating political thought in Enlightenment-era music. If I focus on areas of criticism and disagreement, contending that Charles Nussbaum has imputed to music too simple a set of human goals and purposes and that Steinberg has neglected the role of gender in Mozart's politics, my deep admiration for both books should be presupposed.

\section{The Ancien Regime and the Male Voice: Honor, Shame, Disgust}

According to the received view, Beaumarchais dramatizes the opposition between an ancien regime, based on hierarchy and subordination (personified by the Count) and a new democratic politics, based on equality and liberty (personified by Figaro). The key moment of the Beaumarchais play is thus Figaro's Act $V$ monologue, in which he denounces the Count's hereditary privilege. Mozart, omitting this political speech, has depoliticized the opera, turning the conflict between the Count and Figaro into a merely personal competition over a woman.

This view contains a tacit premise: that the contrast that should hold our interest, as political thinkers, is the opposition between the Count and Figaro. It is because Mozart does not locate the center of the political conflict here that his version is felt not to be political at all, but merely domestic. Let us, however, keep an open mind. Let us not assume that the Figaro represents the new citizenship (as the Count so clearly represents the old).

If we do keep an open mind, we are likely to notice very soon that Figaro and the Count are very similar, both musically and thematically. What do they sing about when they are alone? Outraged honor, the desire for revenge, the pleasure of domination. The energies that drive these two men are not alien, but deeply akin. (Indeed, the two roles are set in such a way that one and the same singer might, in principle, sing either role, and their musical idioms are so alike that it is easy to confuse them. ${ }^{11}$ ) Figaro's initial aria, Se vuol ballare, follows his discovery that the Count has plans to sleep with Susanna. But if we simply look at what Figaro says in the aria, we would not discover that any such creature as Susanna ever existed. All his thoughts are about his rivalry with the Count, and his insistent negatives (non sarà, non sarà) anticipate the Count's peremptory negations at the opera's end (as well as those in the Count's Act III aria). What energizes Figaro? The thought of paying the Count back in kind, teaching him to dance in Figaro's dancing school.

11 Bryn Terfel, for example, well known in performance for his Figaro, has also recorded the Count. 
Similarly, two acts later, the Count imagines Susanna, his own future property, being possessed by Figaro (ei posseder dovrà), whom the Count sees as "a base thing" (un vil oggetto), a mere object. ${ }^{12}$ This thought torments him - not because he is filled with any love or even any particularly intense desire for Susanna, but because the idea of being bested by a mere "thing" is intolerable. To this competitive loss he, like Figaro, has to say "no": "Ah no, I am not willing to allow you to enjoy this happiness in peace. Brazen one, ${ }^{13}$ you were not born to give me torment, and perhaps even to laugh at my unhappiness." Figaro, not Susanna, is the person whom he addresses in the second person. Like Figaro, his head is filled with the picture of another man, laughing at him, insulting his honor, putting him to shame. In return for that tormenting picture, to which he (like Figaro) says "no," he proposes (like Figaro) to substitute the image of a tamed enemy dancing to his tune, in this case the picture of Figaro forced to marry Marcellina and separated forever from Susanna, whom the Count can then enjoy: "Now only the hope of revenge consoles my heart and make me rejoice."14 Figaro's Se vuol ballare is closely based upon the Beaumarchais text; this aria of the Count's, however, is a complete innovation of Da Ponte, since Beaumarchais gives us only what forms the recitative before the aria, not the aria's extended development of sentiments of humiliation and reactive rage.

Musically as well as textually, the Count's aria is a cousin of Figaro's: full of an ill-governed fury that bursts out as the voice reaches the words felice un servo mio, and then again at ah non lasciarti in pace; anger, in the music, is complemented by sneering irony (the downturning phrase accompanying un vil oggetto). The libretto gives us some indication of the kinship between the two men, but the expressive range of the music goes much further to emphasize their rhythmic and accentual similarity, as both express attitudes that range from snide contempt to furious rage. ${ }^{15}$ What emotions are absent? Love, wonder, delight - even grief and longing.

According to the conventional political reading of Beaumarchais, Figaro becomes, by Act $\mathrm{V}$, the apostle of a new type of citizenship, free from hierarchy. Mozart's Figaro makes no such progress. As Michael Steinberg aptly notes, throughout the opera (or, at least, until late in Act IV), Figaro dances, musically, to the Count's tune:

12 The Countess understands that she too is a thing to him: Later, when he addresses her as "Rosina," she replies, "I am no longer she, but the wretched oggetto of your abandonment."

13 I translate audace in this awkward way because to supply "man" or "person" would constitute an acknowledgment that Figaro is human, which is what the Count has just been denying.

14 Literally, the Count speaks of "revenges" in the plural - thinking, presumably, of the way in which he will both force Figaro to marry Marcellina and then humiliate him further by sleeping, himself, with Susanna.

15 For a general account of emotional expression in music, on which I rely here, see M. Nussbaum 2001, chapter 5, whose main contentions are summarized in the Appendix; on the ability of music to go beyond a text, or to make more precise the emotional meaning of an indeterminate text, see the reading of Mahler's Kindertotenlieder in that chapter. 
" $[\mathrm{H}]$ e hasn't found a musical idiom of his own; his political and emotional vocabulary suggests a similarly unfortunate mimetic duplication of the Count's" (Steinberg 2004,43 ) - both in Non più andrai, at the end of Act I (where he reenacts "the authority with which [the Count] has just dispatched Cherubino to serve in one of his regiments, forming his phrases from the relevant military march," (ibid.) and even at the opening of Act IV, when, waiting to catch Susanna in infidelity, he sings, once again, of slighted honor, asking all males to "open your eyes" to the way in which women function as agents of humiliation. Again, it is men, not women, far less a particular woman, whom he addresses in the second person.

Now maybe this means that Mozart has failed to understand the opposition between Figaro and the Count that Beaumarchais has depicted. But let's not pass judgment so quickly. Perhaps, instead, Mozart sees something that Beaumarchais does not see: that the ancien regime has formed men in a certain way, making them utterly preoccupied with rank, status, and shame, and that both high and low partake of this social shaping. What one does not wish to lose, the other wishes to enjoy. For neither, given their obsession, does any space open out in the world for reciprocity or, indeed, for love.

The suspicion that Mozart is deliberately subjecting the male morality of status to critical scrutiny is confirmed when we see what Mozart puts in the mouths of two males who have little to do with the plot. Perhaps, someone might argue, the sentiments of Figaro and the Count are not to be read as serious political thought: after all, the plot requires them to compete in this way. We have seen that even so, Da Ponte constructs a parallel that is not so plain in the original text, and that Mozart takes this similarity much further by giving the two men a similar expressive musical range. Nonetheless, someone might still argue that Mozart and Da Ponte are simply amplifying the suggestions of the Beaumarchais plot. This, however, cannot be said of the treatment of Bartolo and Basilio, whose role in the story line is minimal. Each sings an aria - Bartolo in Act I, Basilio in Act IV (though typically cut in performance) - both of which supply crucial commentary on the morality of maleness. Neither of these arias is based on anything in Beaumarchais' text.

Bartolo is an emotional first cousin of Figaro and the Count. Vocally distinguishable, since he is a basso, he nonetheless sings from the same expressive palate: similar outbursts of rage, tempered by a type of sneering already known to us from Figaro's Se vuol ballare. Textually, his role appears to be to offer a general theory of what Figaro and the Count both exemplify: "Revenge, oh revenge! It is a pleasure reserved for the wise. To forget humiliations and outrages is baseness, is utter lowness." ${ }^{16}$ So, life is more or less utterly occupied by competition for status

16 La vendetta, oh la vendetta è un piacer serbato ai saggi. L'obliar l'onte, gli oltraggi, è bassezza, è ognor viltà. 
and the avoidance of shame between males, and the smart thing to do is to play that game to the hilt. The recommended attitude not only causes outrage and humiliation to eclipse love and longing (Bartolo, like Figaro and the Count, has no thought at all for Rosina, whom he has lost to the Count, through Figaro's scheming), it also precludes any kind of mercy or reconciliation. It is this attitude that leads to the Count's six consecutive "no's" at the opera's end.

Bartolo also shows us something else pertinent to citizenship: for he is very interested in reason and law. His attitude is that the law is an instrument of male revenge, and someone who knows the law will be ahead of someone who does not, because he can find the little weaknesses and loopholes that will allow him to do down his enemy. At this point the aria becomes rapid, joyful, with a kind of sneering playfulness, a patter song of legal one-upmanship: "If I have to search through the whole legal code, if I have to read all the statutes, with an equivocation, with a synonym, I will find some obstacle there. All Seville will know Bartolo! The rascal Figaro will be defeated!" ${ }^{17}$ (Here the music, once again, goes well beyond the text, expressing the sly joy of legal cleverness dragooned into the service of humiliation.) The aria ends four-square and martial as it began (though with a little sneer accompanying the words il birbo Figaro). Bartolo announces that "he" will be known to all: "All Seville will know Bartolo" -- showing us that he takes his practical identity to be utterly encompassed in his revenge project. His joy at the thought is unqualified - despite the fact that the revenge in question would never return Rosina to him. She is simply not on his mind at all.

At the opening of Act IV, another minor character has his say, and it both inverts and ultimately reinforces the morality of Bartolo. Basilio, a music-master, is a less powerful character than Bartolo, and it was he who, in the predecessor play The Barber of Seville, discoursed enthusiastically on the crushing humiliation that gossip and slander can offer someone who wants to defeat an enemy. Da Ponte portrays him throughout as both spiteful and weak, lacking the resources to compete on an equal footing with the nobles, lacking the cleverness to compete on an equal footing with Figaro. His Act IV aria offers advice to men who are in this weakened position. ${ }^{18} \mathrm{He}$ begins by telling the audience that it is always risky to enter a competition with the grandi: they almost always win. So, what should one do? A story from his youth offers guidance. He used to be impulsive, and didn't listen to reason; then, however, Lady Prudence made her appearance before him, and handed him the skin of an ass. He had no idea what it was for, but when, shortly after that, a thunderstorm began, he covered himself in that ass's skin. When the storm abated he looked up - and found a terrible beast before him,

17 Se tutto il codice dovessi volgere, se tutto l'iindice dovessi leggere, Con unequivoco, con un sinonimo, qualche garbuglio si troverà. Tutta Siviglia conosce Bartolo: il birbo Figaro vinto sarà.

18 Because this aria is so commonly cut it is not in the Dover edition of the libretto, and so I use the text from the libretto accompanying the 1983 Solti recording of the opera. 
almost touching him with his mouth. He could never have defended himself from a terrible death. But: the disgusting smell of the ass's skin scared the beast away. "Thus fate taught me that shame, danger, disgrace, and death can be escaped under an ass's skin." 19

This aria offers advice diametrically opposed to the advice in Bartolo's, which told us to use reason and law to hound the person who has caused one's humiliation. It's obvious, however, that the difference is slight. Both men see the world in the same way, as a zero-sum game for honor and status. The only difference is that Basilio is aware that some are bound to be losers, and he wants to give advice about damage control to those losers. If you are perceived as smelly and low anyway, use that spoiled identity to protect yourself from yet further outrage. Sung in a sneering reedy tenor, the aria, like Bartolo's, complements Figaro and the Count from the other direction. It shares with them a view of what the world is really about. If women figure in the aria at all, it is only in the way Basilio confesses to a kind of "fire" and "craziness" in his youth - a false direction soon put right by the counsels of Lady Prudence. The ancien regime does not like low-class people who allow their fire free rein.

\section{Females: Fraternity, Equality, Liberty}

The females of the opera inhabit a musical and textual world that is from the beginning depicted as utterly unlike that of the men. First of all, it contains friendship. Susanna and the Countess might have seen one another as rivals: after all, the Count is trying to seduce Susanna. However, the thought does not occur to them: they understand that they share a common set of purposes, and that the desired outcome for both is that both men, Figaro and the Count, become loving and faithful husbands focused on affection and pleasure, rather than revenge and jealousy. (The Count is as dominated by jealousy as is Figaro, despite his apparent lack of love for his wife.) Like the two men, the two women share a musical idiom - so much so that they can be mistaken for one another even by the men who ostensibly love them (until, interestingly, Figaro does at least recognize Susanna by her voice, "the voice that I love").

Unlike the men, however, the women use their similarity not for mutual combat but for cooperation, and, in particular, for the complex masquerade that ends up revealing the Count's hypocrisy. When we focus on their teamwork, we notice, as well, that there is absolutely nothing like teamwork and reciprocity among the men. The women's partnership, moreover, despite their class difference, appears to be quite unhierarchical, as they benefit one another with genuine mutual friendliness.

19 Cosi conoscere me fe'la sorte ch'onte, pericoli, vergogna e morte col cuoio d'asino fuggir si può. 
(Susanna, for example, is surprised that it is she - presumably not all that well educated - who is to write the letter to the Count suggesting the rendezvous: "I should write? But madame....". The Countess will have nothing of her deference: "Write, I say, and I will take the consequences.") One way we see their reciprocity is in the nature of their jokes: for here there are no sneering put-downs, no snide spitefulness, only mutual solidarity and the equal love of a good scheme.

Once again, all this is in the libretto: but the music takes the suggestion of reciprocity and equality much further. As Countess dictates the letter and Susanna writes it down, the women take inspiration from one another's musical phrases, exchanging ideas with a sinuous capacity for response and a heightened awareness of the other's pitch, rhythm, and even timbre. They begin by exchanging phrases, as in a conversation. As the duet continues, however, their reciprocity becomes more intimate and more complex, as they wind around one another, ultimately achieving closely-knit harmony. Their musical partnership expresses a kind of friendly attunement that is, we might say, an image of mutual respect, but also a reciprocal affection that is deeper than respect. Neither runs roughshod over the utterance of the other, and yet each contributes something distinctive of her own, which in turn is recognized by the other, and carried forward..$^{20}$

This duet has acquired fame in American popular culture because of its use in the film version of Stephen King's The Shawshank Redemption, when Tim Robbins, the convict who has become the prison's librarian, figures out a way to play it for all the prisoners over the PA system, and, locking the door, stops the prison hierarchy from interfering until the duet is done. The men of Shawshank certainly are not fans of classical music, but they hear something in this music, and stop in their tracks, transfixed by a promise of happiness. As Morgan Freeman expresses it, looking back:

I have no idea what those two Italian ladies were singing about. Truth is, I don't want to know. Some things are better left unsaid. l'd like to think they were singing about something so beautiful, it can't be expressed in words, and it makes your heart ache because of it...,and for the briefest of moments, every last man in Shawshank felt free.

What do the prisoners hear in the duet? Freedom, they say. But why, and how? First, they cannot help hearing an absence of hierarchy in the evenly-matched voices, and a partnership based on responsiveness rather than dictatorial power. This, in the context of Shawshank, is already freedom. But, as the voices soar out over the squalor of the prison yard, I think there is more to be heard in it: the idea of a kind of internal freedom, a freedom of the spirit that consists precisely in not caring

20 For discussion of a similar moment in the final movement of Mahler's Second Symphony, the contralto and soprano voices wrapping around one another, see M. Nussbaum 2001, chapter 15. I now believe that Mahler, the lifelong opera conductor, may have derived the inspiration for this musical depiction of reciprocity from Figaro. It is also, as he makes clear, an image of freedom. 
about hierarchy, neither seeking to avoid being controlled by others nor seeking to control them. Suppose we imagine Tim Robbins playing the Count's Vedrò mentrio sospiro, or Bartolo's La vendetta. Well, those two powerful men express, in their own way, an idea of freedom: freedom as power to dominate, escaping the shame of being dominated. But we know that the men of Shawshank would not have been transfixed by that image of freedom: after all, it is what they live every day. The promise of the duet is not simply a promise of freedom as reversal, freedom as getting your turn to humiliate the one who has humiliated you. It is a freedom that takes us beyond that anxious and always unsettled picture of what liberty, for men, might consist in. It is freedom as being happy to have an equal beside you, freedom as not caring who is above or beneath. And that's a freedom that does take the mind way away from Shawshank, and from the American society of which that institution is the apt mirror.

In other words, this music has invented democratic reciprocity. Whatever the faults of the film - which is in many ways sentimental - this moment contains a correct insight into Mozart's politics and into the politics of equality more generally. You don't get the right kind of liberty, the idea is, without also having this type of fraternity and this type of equality. To shoot for liberty without fraternity, as Beaumarchais' Figaro does, is simply to turn the hierarchy upside down, not to replace it with something fundamentally different. If there is to be a new regime, if there is ever to be something like a politics of equal respect in this world, the suggestion is, it must start by singing like those two women, and this means becoming a fundamentally different type of man. ${ }^{21}$

To put it a different way: the male world of Figaro is its own prison, as each man goes through life dominated by rank-anxiety. What those prisoners heard in the

21 Where, if ever in opera, do men sing like that (in close-knit interweaving harmonies, each taking cues from the other)? The duet in Bizet's The Pearl Fishers comes to mind, but it is not nearly as complex: the men simply sing together in close harmony. Similar is the wonderful liberty duet (Dio, che nell'alma infondere) sung by Carlos and Roderigo in Verdi's Don Carlo - close harmony and, we might say, solidarity, but without responsiveness to the separate moves of the other. So it would seem that men, in opera, can on occasion attain solidarity and unanimity, but perhaps not responsiveness or attunement. One might also study the Otello-lago duet in Verdi's Othello, where they both swear vengeance together. Here there is an appearance of attunement, but it is only superficial, since at a deeper level the two are profoundly at odds; such attunement as there is is profoundly unhealthy. I welcome other examples and counter-examples.

As for men and women singing together with the responsiveness of the Countess and Susanna, the supreme example that comes to mind is a strange one: the final love duet, Pur ti miro pur ti godo, pur ti stringo, pur t'annodo ("I wonder at you, I enjoy you, I embrace you, I entwine you”) sung by Nero and Poppaea, alone on the stage, at the end of Monteverdi's L'incoronazione di Poppaea. There, the expressive purpose of the sinuous and intertwining lines (sung, usually though not always, by two female voices) is to express and represent the reciprocity of good lovemaking - an idea not irrelevant to this moment in Figaro, as we notice that the women's capacities for responsiveness are sadly unmatched by any similar capacity on the part of the men they love. However, in Monteverdi the political intention is clearly to show that people are not all of a piece: the brutal tyrant Nero, who has just killed Seneca and many other good people, is capable of the most respectful and egalitarian sort of sexual passion. Figaro is more skeptical: brutality in the public domain is very unlikely to be accompanied by anything else in the private, and vice versa. 
duet was the promise of a world without that tension, a world in which one would then really be free to engage in the pursuit of happiness. The new regime, as it never has been realized in any nation in the world. ${ }^{22}$

\section{Creating a Man: "Mischievous Looks," a "Good Outside Myself"}

The headings of the last two sections referred to "females," but to "the male voice," and it is the male voice, not maleness itself, that the opera associates with the endless and exhausting fight against the "lowness" of shame. There is, however, a male in the opera who does not sing in a male voice: the teenage boy Cherubino, performed by a female mezzo-soprano. This already seems significant: and Cherubino's education, it shortly emerges, is the focal point of the opera's depiction of the new egalitarian citizenship.

Cherubino is usually treated superficially, as a running joke throughout the opera, and this is, more or less, the way Beaumarchais treats him. His preoccupation with women and sex is indeed the source of much of the plot, as he turns up repeatedly in places where he should not be, to the consternation of the possessive males around him. In many productions he is treated as a person with no sentiments, but only very intense bodily desires. Let us, however, pay closer attention to what he says and what he does.

Cherubino is clearly, in crucial ways, masculine. He is tall (Susanna has to ask him to kneel down so that she can put on his bonnet), good looking (Figaro and the Count are both jealous of him), and sexually active (with his teenage girlfriend Barbarina) -- indeed, very likely, the only male who is actually having sex with anyone during the time span of the opera. ${ }^{23}$ On the other hand, the fact that he is sung by a female voice forces us to pay attention to the ways in which that voice, and the sentiments it expresses, differs from all the male voices in the opera. So, what does Cherubino talk about?

He talks about love. He is the only male in the opera who has the slightest interest in that emotion. Certainly, the breathlessness of Non so più expresses the

22 This new world surely involves transformation on the part of real-life women as well - for although the world of males has its distinctive pathologies, it would be absurd to claim that the world of real-life women is a stranger to jealousy and rivalry. (We should not forget Susanna's sniping at Marcellina, and vice versa, in that Act I duet - although that rivalry is harmoniously resolved soon enough.) In this sense we ought to view Mozart's men and women as symbolic place-holders for types of human beings that one might be, or become.

23 The Countess is eloquent about her husband's neglect and indifference. So much is made of the idea of Susanna's virginity at the time of marriage that it seems plausible to think that she and Figaro have not yet occupied the bed that he is so anxiously measuring at the opera's opening. 
promiscuous quality, as well as the confusion, of adolescent infatuation: "Every woman makes me blush, every woman makes my heart leap." Still, even when he is reporting his state of sexual obsession, he is talking about love: "I talk about love when I'm awake, I talk about love in my dreams, I talk about it to the water, to the shadow, to the mountains, to the flowers, to the grass, to the fountains, to the echo, to the air, to the winds." ${ }^{24} \mathrm{He}$ shows, here, a romantic and poetic conception of what he is after that is quite unlike the ideas of all the other males in the opera, who all see sex as a means of asserting domination over a key piece of property in the male world. The musical idiom, breathless and yet tender, is utterly unlike the tense accents of the adult males. Indeed, it is the musical idiom, far more than the Beaumarchais-inspired text, which makes us see that Cherubino's sensibility is poetic and romantic, rather than simply energetic.

When we reach the Countess's chamber, Cherubino's difference from other males becomes even more evident. Deeply infatuated with the Countess, he has decided to make her a present. What sort of present? What naturally occurs to him is to write a poem, set it to music, and sing it himself. Thus, accompanying himself on the guitar, Cherubino becomes the only leading character in the opera who sings a solo, that is, whose solo singing represents singing. ${ }^{25}$ Growing up in a world of sentiment and musicality, he naturally gives his passion a musical shape. ${ }^{26}$

The content of that passion (in the beautiful area Voi che sapete) is remarkable for its utter difference from the arias of all the other males. First of all, Cherubino simply talks about his feeling of love, and about its beautiful female object. He has nothing to say about other men, and he seems utterly impervious to all questions of honor, shame, and competition. Second, he is eager to learn something, and he is eager to learn it from women: "You who know what sort of thing love is, women, tell me whether that is what I have in my heart." All the other men are eager to teach rather than to learn; what they are eager to teach is a lesson in competitive one-upsmanship, and they are eager to teach it to other males. (Figaro imagines

24 Da Ponte has altered Beaumarchais here in an interesting way: in Beaumarchais, the passage goes, "Finally, the need to say 'I love you' to someone has become so urgent for me that I say it when I'm all alone, when I'm running in the park, I say it to your mistress, to you, to the trees, to the clouds, to the wind that carries the clouds and my lost words away together." This comically confused utterance - he can hardly tell the difference between one woman and another, or between a woman and a tree - is subtly altered by Da Ponte into something much more delicate, a mood that the musical idea brings out more vividly still.

25 I say "leading character," because the various choruses saluting the Count for his wisdom and virtue - "Giovani liete," "Ricevete, o padroncina," and "Amanti costanti" are presumably to be imagined as real-life singing inside the plot: Figaro at one point says, "the music-makers are already here." I say "solo" because of the duet between Susanna and the Countess, the "canzonetta sull'aria," already discussed.

26 In Beaumarchais he simply takes a traditional folk melody and writes his own words to it. The words themselves express love for the Countess, though they are far less interesting than the Da Ponte text; the music, however, is utterly banal, the tune of "Malbrough s'en va-t-en guerre," a bouncy somewhat aggressive war song. 
himself as the dance-master running a school that will teach the Count to dance to his tune; Bartolo is eager to show "all Seville" that he can defeat Figaro; the Count is eager to show Figaro that his "cause" is not, as Figaro believes, "won," but, rather, lost.) Third, Cherubino, unlike all the other males, is utterly vulnerable, and he makes no attempt to conceal his vulnerability, which is emotional more than bodily: "I feel my soul in flames, and then it turns to ice in a moment." He describes an intense longing that leaves him no peace. Finally, and most remarkably, he locates what he is pursuing in a place outside of his own ego: "I seek a good that is outside myself" (ricerco un bene fuori di me). Hearing these words, we realize that no other male in the opera does seek a good outside himself: all are preoccupied with winning a competitive victory, or shielding the ego from shame.

The music of the aria would tell us all this without the words, and indeed it communicates, well beyond the words, the young man's delicacy, vulnerability, and sheer kindness. Indeed it is hardly by accident that people who have utterly no idea what Cherubino is saying should have found in this aria (as in the duet between Susanna and the Countess) an image of emotional integrity.

How did Cherubino get to be this way, a way that promises real reciprocity in passion? Answer: he was brought up by women and kept a stranger to the men's world. Indeed, we've already seen that the prospect of military service utterly confuses and appalls him. In the scene, at the end of Act I, in which Figaro tells him what to expect when he goes off to the army (Non più andrai), Figaro's joke to Cherubino is that he has lived in the women's world of sentiment, music, tenderness, and delicacy -- and now, suddenly, he will have to enter a world of drunken men (they swear by Bacchus) with inflexible necks (collo dritto), tough faces (muso franco), long mustaches (gran mustacchi), and "lots of honor" (molto onor). Now, in Act II, we see more fully how much the young man will have to unlearn in order to enter this male world: in particular, lovely, sensuous music. "What a beautiful voice," says the Countess when Cherubino finishes his aria drawing attention, again, to the fact that this is singing singing. Figaro has already told Cherubino, however, that the world of male honor knows nothing of beautiful music: Its only music is "the concerto of trumpets, of shells and cannons, whose shots, on all pitches, make your ears whistle." ${ }^{27}$ The aria itself, with its boringly four-square military rhythm, now, in retrospect, contrasts sadly with the grace and elegance of Cherubino's composition.

By singing so beautifully, Cherubino shows himself to be a candidate for fraternity, equality, and the female type of liberty. But before he can be finally confirmed as lovable-with-good reason, one thing more must happen to him: he must put on

27 “...al concerto di tromboni, Di bombarde, di cannoni, Che le palle in tutti i tuoni All'orecchino fan fischiar.' 
women's clothes. The plot requires the disguise, but Mozart connects this moment to the deeper sentiments of the heart.

It has often been sensed that Susanna's tender aria, "Come, kneel down," Venite, inginocchiattevi, is a pivotal moment in the opera, that something profound is going on when Susanna, first perfecting Cherubino's female disguise, then takes a look at him and sings, "If women fall in love with him, they certainly have their good reasons" (se l'amano le femmine, han certo il lor perchè. The music is perhaps the most sensuous and tender in the opera, as Susanna, asking him to turn around, adjusts his collar and his hands, shows him how to walk like a woman - and then notices how the guise complements the young man's mischievous eyes and graceful bearing: che furba guardatura, che vezzo, che figura! What Mozart slyly suggests, by making this aria so riveting, and, at the same time, so playful, is that here, in an intimate moment of tenderness, that the seeds of overthrow for the ancien regime are decisively sown.

To begin with, the aria concerns kneeling. There is lots of kneeling in this opera, and in every other place (until the very final moments) kneeling is a symbol of feudal hierarchy: exalted status on the one side, obedience on the other. In the women's democratic world, however, kneeling is just kneeling. You kneel in front of your dressmaker so that she can fix your bonnet and collar. Kneeling has no symbolism, it is just a useful action. Hierarchy is simply out the window, irrelevant, a non-issue. The music itself expresses this thought: instead of the thumping accents of the quest for honor, we hear little trill-like bursts from the violins, playful jumpings, like muffled outbursts of laughter, that not only betray no hierarchy, but that positively subvert the whole idea. ${ }^{28}$ Bit by bit, the woman's costume is assembled, the woman's walk learned - until, at the end, Susanna surveys, with wonder and amazement, the result she has produced. "Admire (mirate, wonder at) the little devil, admire how beautiful he is. What mischievous looks (che furba guardatura), what charm, what allure. If women love him, they certainly have their good reasons." Cherubino is alluring, it seems, precisely because, while manly and drawn to women, he is not drawn to controlling them or using them as pawns in games with other men: instead of domination, charm and grace; instead of plots to conceal shame or avenge insult, "mischievous looks," as he joins the women in their love of jokes and gossip. ${ }^{29}$

28 A possible allusion in the text is to the Christmas carol venite adoremus, $\mathrm{O}$ come let us adore him (which would often be a prelude to kneeling). Here, Susanna says, "Come, kneel down" - but it is not adoration of the transcendent that she seeks, it is fun and play.

29 Here Da Ponte has made major alterations to Beaumarchais. The stage direction says that Cherubino kneels, but Susanna does not ask, so the inversion of feudal kneeling is not emphasized. Far more important, when Cherubino becomes a woman Susanna says that she, as a woman, is jealous of him. This not only puts rivalry and jealousy into the women's world, whereas Mozart and Da Ponte represent that world as a world of reciprocity; it also fails to state that a man is more attractive as a man for behaving in ways that we have heretofore associated with that world. 
All of this is in the libretto - after a fashion. We can, however, imagine musical settings of the text that would have signaled irony, or skepticism, or bitterness (certainly an emotion that we could imagine Susanna feeling at this time). Instead, the music expresses both tender sensuousness and, as I have said, with the playful movements of the strings, laughter, suggesting that these two attitudes go well together, and that both are key parts of the woman's world. We are now led to recall a feature of the Overture whose significance we might have missed before: the same type of muffled laughter from the violins is present there, suggesting that subversive play is a major theme of the opera as a whole.

This reading of the aria is shortly confirmed by the duet Aprite, presto, aprite, as Susanna and Cherubino plot together about getting him safely out of his compromising hiding place. The two sing, extremely rapidly, in hushed conspiratorial voices that show a rare degree of attunement - foreshadowing the more developed duet between Susanna and the Countess in Act III. Cherubino shows that he has now, in effect, become a woman: a co-conspirator, a voice of fraternity and equality, and therefore, as if we didn't know it already, a person internally free from the bonds of status.

As we look at Cherubino, we realize afresh how un-radical Figaro's apparent radicalism is. It's not only that he takes over from the ancien regime its proprietary attitude to women; it's something more global than that. Figaro simply sees the world the way the Count sees it: in terms of the quest for honor and the avoidance of shame. He doesn't understand reciprocity, and he really doesn't understand humor. (His idea of a joke is a mean-spirited put-down.) If the new world has citizens like that, its commitment to equality and fraternity will be bound to be problematic. New hierarchies will be thrown up to replace the old, like ramparts defending the male ego. Could there, however, be citizens who simply like to laugh and to sing?

In her fascinating reflections on eighteenth-century pornography, Lynn Hunt has argued that the pornographic idea of the interchangeability of bodies is closely linked to the revolutionary call for democratic equality (Hunt 1993, 44). ${ }^{30}$ Legal theorist Lior Barschack argues that the new subjectivity created by Mozart's operas is just this hedonistic idea of sexual freedom (Barshack 2008). ${ }^{31}$ No doubt such ideas were prominent in the eighteenth century, as people (meaning men) tried to make sense of the new world they inhabited.

30 Robert Darnton's earlier study of eighteenth-century pornography (and, in particular, of the anonymous novel Therèse Philosophe) comes to a subtly different conclusion: the new idea is not one of intersubstitutability of bodies, but rather the idea of women's control and autonomy: thus the relationships that are prized are personal and long-lasting, but include contraception. See Darnton 1997.

31 Later, Barshack $(2008,63)$ seems to arrive at a more nuanced view: "as Mozart saw, the libertine account of humaneness is as one-sided as the sentimental"; but I'm not sure I have fully understood his argument at that point, or how it is related to his earlier contention. 
If I am right, however, Mozart sees the world rather differently, and more radically. The objectification of bodies as interchangeable physical units is itself, the opera suggests, just one aspect of the ancien regime, which invented and depends upon the idea that some classes of people, including, prominently, women, are just oggetti, and thus can be used at will in one's quest for personal gratification. Seeing bodies as interchangeable is, indeed, a clever route to what the ancien regime wanted all along: male control and invulnerability. What would be truly opposed to the ancien regime would be, not the democratization of bodies as interchangeable machines, but - love. Which, as Cherubino understands, means seeking a good outside oneself, a scary idea.

What's suggested here, then, is that democratic reciprocity needs love. Why? Why wouldn't respect be enough? Well, first of all, respect is unstable unless love can be reinvented in a way that does not make people obsessed all the time with hierarchy and status. That private obsession, unchallenged, threatens to disrupt the public culture of equality. But, more deeply, the public culture needs to be nourished and sustained by something that lies deep in the human heart and taps its most powerful sentiments, including both passion and humor. Without these, the public culture remains wafer-thin and passionless, without the ability to motivate people to make any sacrifice of their personal self-interest for the sake of the common good (M. Nussbaum 2008).

\section{Cherubino, Rousseau, Herder: Spaces for Craziness, "Dispositions of Peace"}

Now that we have a general idea of what Mozart is attempting, we may make our impressions more precise by comparing the opera's insights about citizenship in the new era to those of two of Mozart's philosophical contemporaries, JeanJacques Rousseau and Johann Gottfried Herder. Both share with Mozart the view that a new political culture needs to be sustained by new sentiments, and both also share with him the view that these sentiments must be not only the calm sentiments of respect and civic friendship, but must include, and be sustained by, something more like love, directed at the nation and its moral goals. Here, however, the resemblance ends.

In the important final section of On the Social Contract entitled "On Civil Religion," Rousseau makes it clear that intense love-like bonds of patriotic sentiment are needed to bring citizens together, rendering egalitarian institutions stable over time. ${ }^{32}$ Early in human history, he observes, people "had no kings but the gods,"

32 I am citing the work in the translation of Rousseau (1987), original publication 1762; page numbers are from that edition. 
and needed to believe that their leaders were indeed gods. Both paganism and feudalism were sustained by some such fiction. "A lengthy alteration of feelings and ideas is necessary before men can be resolved to accept a fellow man as a master, in the hope that things will turn out well for having done so" (220). These new sentiments must have the intensity of the religious sentiments they replace, or they will not succeed in holding the new political order together.

Christianity looks at first blush as if it might be that "civil religion," since it does teach the brotherhood of all human beings (224). On further inspection, however, Christianity has a number of fatal flaws from the point of view of the political order. First, it teaches people to hope for a salvation that is other-worldly and spiritual, rather than political; thus "it leaves laws with only the force the laws derive from themselves, without adding any other force to them" (224). Second, Christianity turns people's thoughts inward, as each is urged to examine his own heart; this teaching produces indifference to political events. Third and finally, Christianity teaches non-violence and even martyrdom, thus teaching people to be slaves. "Its spirit is too favorable to tyranny for tyranny not to take advantage of it at all times" (225). Christian emperors, Rousseau argues, ruined the Roman empire: "when the cross expelled the eagle, all Roman valor disappeared" (225).

The civil religion we need must inculcate "sentiments of sociability, without which it is impossible to be a good citizen or a faithful subject" (226). These sentiments are based on some quasi-religious dogmas, including "the sanctity of the social contract and the laws" (226). But what are the sentiments themselves like? It is clear that they involve an intense love of the nation and its laws. They also involve a type of fraternity grounded in unanimity and homogeneity: the person who dissents from the "civil religion" is to be banished "for being unsociable, for being incapable of sincerely loving the laws and justice" (226). Civic love, then, is incompatible with active critical thought about the political order, and with a sense of the separateness of the individual from the group. The test for sincerity is unanimity. Furthermore, one thing that citizens must be unanimous about is the willingness to die for the nation - presumably without thinking critically about the plan for war, and whenever the sovereign body of citizens so decrees. The sentiment of civil love has, then, a strong commitment to the suspension of both individuality and reasoning. Indeed, we might say, more generally, that the person-to-person dimension is missing, since the approved sentiments of communal bonding do not lead to or rest upon any sentiments directed at individuals, even sentiments of concern and respect. ${ }^{33}$

Notice, then, that despite Rousseau's intense hatred of the feudal order, he has not been able to think his way very far beyond it, in thinking about the emotions.

33 I owe this point to Daniel Brudney, who also points out that the Letter to d'Alembert on the Theater contains a rather different picture of the preferred types of social interaction. 
Civic love, like feudal love, is obedient, hierarchical. (Even if "the general will" is sovereign, not an individual, it nonetheless bears to the wayward individual a strongly hierarchical relationship.) There is no room for the sort of reciprocity exemplified by Mozart's women, a reciprocity based on plotting, joking, a sense of the free space within which people can live and be themselves. Moreover, despite Rousseau's attempt, in Book IV of Emile, to substitute the egalitarian sentiment of pitié for sentiments based upon feudal inequality, that experiment remains deeply unrealized in his idea of the civil religion, since the civil religion counters the allegedly excessive meekness of Christianity by relying, it would seem, on the very ideas of manly courage, assertiveness, and honor that sustained the ancien regime. There is a shift, in that the object of civic shame, civic anger, and civic assertiveness is now the nation, seen as embodiment of the general will. The sentiments themselves, however, feel very much the same, as the nation seeks to establish itself in the world's hierarchy of nations. It's still true, in this new world as in the old, that "to forget shame and insult is baseness, complete lowness of status."

Mozart, by contrast, proposes a radical alteration of the very content of civic love. No longer must love revolve in any way around ideas of hierarchy and status. Instead, it must be aspirational: like Cherubino, it must "seek a good outside myself."

To sustain truly egalitarian institutions, moreover, this aspirational love must remain vulnerable to criticism, ultimately to the fact that each individual has a quirky mind that is not exactly the same as any other. Rather than Rousseau's homogeneity, the Mozartian regime seeks real-life heterogeneity, gives it space to unfold, and takes delight in its oddness. The fondness of the women's world for plotting, joking, every subversion of tradition and obedience, is the sign of something that ultimately becomes crucial to the Enlightenment, in its Kantian and especially Millian forms: the idea of the mind of the individual as containing an untouched free space, a funny unevenness that is both erotic and precious. What the women's world knows is that those "mischievous looks" are precisely what make Cherubino worth loving (so that, if women love him, they "certainly have their good reasons"). They also know that the aspirational nature of his love is deeply interwoven with his capacity for subversion. Civic love, then, also has a downward movement: it can aspire in a healthy way only if it is also capable of poking fun at itself, noticing the everyday messiness and heterogeneity of real people. ${ }^{34}$

How do we imagine this civic love expressing itself? We connect Rousseau's love with solemn public ceremonies, with anthems, with the drumbeat of the call to arms. Mozart's love, by contrast, is expressed - well, through many different types of artistic and musical performance, but, crucially, through comedy, including

34 This idea of the two aspects of decent patriotism is a central theme in M. Nussbaum and J. Israel, Loving the Nation: Toward a New Patriotism, book in progress (under contract to Basic Books). 
comedy that pokes fun at the call to arms (as in Non più andrai) and points out some of the unpleasant realities of what passes in some quarters for warlike glory: "instead of the fandango, a march through the mud (il fango)." ${ }^{35}$

At this point, we notice that Mozart has an eighteenth-century ally: Johann Gottfried Herder, whose Letters for the Advancement of Humanity (1793-7) develops a remarkably similar conception of a reformed patriotism that would need to be inculcated if the world were ever to become a world of peace. Herder begins by making the point that if patriotism is an attitude toward an entity called "Fatherland," it had better figure out what is valuable in the relationship of a child to its father (Herder 2002, 378). If we ask this question seriously, he argues, we will see that we want this love to contain aspiration to genuine merit, but also a love of peace, since we all remember with greatest longing and love the peaceful times of our childhood. Moreover, what delighted us in those peaceful times was "games of youth" : so, the new patriotism must at the same time be something playful. Above all, it would never involve blood lust and revenge: "Fatherlands against fatherlands in a combat of blood [Blutkampf] is the worst barbarism in the human language."

Later in the collection, Herder returns to this theme, making it clear that he conceives of the animating spirit of the new patriotism as less paternal than feminine, and requiring a profound gender transformation on the part of males. Here he alludes to what he has managed to learn about Native American Iroquois customs, which, he argues, involve casting one of the potentially warring tribes in the role of "the woman," and then requiring all the others to listen to what "she" says: 36

Hence if at some time the men around her are at blows with each other and the war threatens to become severe, then the woman should have the power to address them and say to them: "You men, what are you doing that you belabor each other about with blows in this way? Just remember that your wives and children are bound to die if you do not stop. Do you, then, want to be responsible for your own annihilation from the face of the earth?" And the men should then pay heed to the woman and obey her. (401)

By dressing the (members of the) chosen nation in women's skirts and women's jewelry, they express the thought that "from now on they should no longer occupy themselves with weapons" (401). Herder now notes that the members of the Iroquois nation address one another as "sister-children" and "fellow female playmates."

Now to Europe. Herder observes that at one time feudal hierarchy played, after a fashion, the role of this "woman," making people keep the peace. Now that we have rejected feudalism, however, we have to put the women's clothes on all of

35 Here I echo ideas already developed by Israel in the above draft, in writing about the wartime cartoons of Bill Mauldin.

36 Here Herder is apparently paraphrasing a writer named G. H. Loskiel (1740-1814), a priest of the United Brethren, who published an extensive account of Iroquois customs in 1794. 
us, in effect, and this means inculcating in all citizens "dispositions of peace." His "great peace woman" (whom he equates with "universal justice, humaneness, active reason") will seek to produce seven (emotional) "dispositions" in the citizens of the future. First is a "horror of war": citizens should learn that any war not limited to self-defense is mad and ignoble, causing endless practical pain and deep moral degeneration. Second, they will learn "reduced respect for heroic glory." They should "unite to blow away the false sparkle that dances around a Marius, Sulla, Attila, Genghis Khan, Tamerlane" - until citizens have no more awe for these mythic "heroes" than they do for common thugs. Herder does not say how this "blowing away" should be accomplished, but comedy is clearly a useful technique. Third, the peace-woman will teach a "horror of false statecraft." It's not enough to unmask warlike heroics: we must also teach disobedience and disrespect to the sort of political authority that likes to whip up war to advance its own power-interests. To produce this result we must teach active critical citizenship: "The universal voicevote must be victorious over the value of mere state rank and of its emblems, even over the most seductive tricks of vanity, even over early-imbibed prejudices" (406). Of course this critical spirit must be taught in conjunction with an admiration for and aspiration to what is really fine.

Fourth, peace will teach patriotism, but a patriotic love that is "purified" of "dross," above all purified of the need to define the lovable qualities of one's nation in terms of competition with other nations, and even war against them. "Every nation must learn to feel that it becomes great, beautiful, noble, rich, well ordered, active, and happy, not in the eyes of others, not in the mouth of posterity, but only in itself, in its own self." (406) The fifth, closely related, disposition is that of "feelings of justice towards other nations." The sixth is a disposition to fair principles for trade relations, involving a ban on monopoly of the seas and a determination to make sure that poorer nations are not sacrificed to the greedy interests of the richer. Finally, citizens will learn to delight in useful activity: "the maize stalk in the Indian woman's hand is itself a weapon against the sword." All of these, concludes Herder, are the principles "of the great peace goddess Reason from whose language no one can in the end escape" (408).

Herder and Mozart are in harmony. Each sees the need to feminize the culture of male one-upmanship, if civic love is to be productive of true happiness. The Countess, we might say, is Herder's great peace-woman Reason, whose gentleness and whose refusal to focus on insulted pride show a way in which "all" can be happy. And Cherubino, her pupil, has learned from her a horror of war, a horror of false statecraft, and a love of mischievous subversion of the countless ways in which men try to make the world a world of war. The adult men are led, in the end, to put on those long skirts and think about daily life in a reasonable way, rather than a way informed solely by the insatiable greed of honor run amok. What we have in the end of the opera is something that would appall Rousseau, a world 
of craziness, foolishness, joking, idiosyncratic individuality -- and, inseparably, a world of peace. It's the world that Kant and Mill would have depicted, if either of them had had a sense of humor.

\section{Transcending the Everyday? Nussbaum contra Nussbaum}

What, then, happens at the opera's close? Temporarily, at least, the male world yields before the female world, asking for pardon. And then there is a pause. As Steinberg $(2004,45)$ nicely says, "[F]rom Mozart to Mahler, the rest, the musical pause, the moment of silence is the indicator of a first-person musical voice taking stock of itself. Music stops to think." ${ }^{37}$ And what, in this silence, might the Countess be thinking, before she says "Yes"?

If she has any sense - and we know that she has a great deal - she will be thinking, What on earth does this promise of renewed love really mean? Has this man, who has behaved badly for years, really become a new person just because our joke succeeded and he is publicly embarrassed? And when, like the sensible woman she is, she gives herself the answer, "Surely not," then she must think again, asking herself, "But then, shall I accept him as he is, with his arrogance, his status-consciousness, his anxiety-driven infidelities? Shall I agree to live with just the hope or promise, and the occasional reality, of reciprocal love, rather than its assured stability?

When, then, after that pause, she answers "I am nicer, and I say yes," with that downward-leaning phrase, she is saying yes to the imperfection in all their lives, accepting the fact that love between these men and these women, if frequently real, will always be uneven and far from blissful; that people will never get the entirety of what they long for; that even if men are capable of learning from women - and Steinberg (ibid., 45-46) has nicely shown how Figaro learns from Susanna a newly tender musical idiom ${ }^{38}$ - nonetheless we hardly have reason to expect these achievements to be stable, given the pressures culture and upbringing exert on human development. Indeed, it seems far more likely that Cherubino will be corrupted by the male world around him than that the other men will drop their quest for honor and status and learn to sing like Cherubino. Even in the best of cultures, the aversion to shame and the narcissistic desire for control are profound human desires; they are unlikely to go away, yielding a world in which all lovers get

$37 \mathrm{He}$ is talking about a pause in Susanna's aria Deh vieni, non tardar, which he discusses so nicely that I refrain from adding anything further.

38 "In his emotional maturity, Figaro is awarded by Mozart with a musical sensuality that departs from his earlier, metronomic ditties." 
everything they want. (And wouldn't the image of such a world itself be a narcissistic fantasy that might inhibit the real perception of another individual reality?)

So, when she says that "yes," she is agreeing to love, and even trust, in a world of inconstancy and imperfection -- an affirmation requiring more courage than any of the battlefield exploits mentioned by Figaro in Non più andrai.

And what she agrees to, here, is also what the ensemble also agrees to. The new public world is a world of happiness in that way. What that seems to mean is that all present say yes to a world that seeks and aims at reciprocity, respect, and attunement without being starry-eyed about perfection, a world in which people commit themselves to liberty, fraternity, and equality, while understanding that these transcendent ideals are not to be attained by exiting from the real world into a pristine world, but rather by pursuing them in this one, in episodes of love and craziness. The new regime will fail if it demands perfection. It will succeed only on the basis of a realistic conception of men and women, and what they are capable of. But sustaining the hope of fraternity without being starry-eyed (and therefore, in due course, disillusioned and cynical) requires something like an unjaundiced trust in the possibility of love (at least sometimes and for a while), and, perhaps above all, a sense of humor about the world as it is. ${ }^{39}$

In his magnificent new book, The Musical Representation: Meaning, Ontology, and Emotion, Charles $\mathrm{O}$. Nussbaum gives us the best picture we have in philosophy to date of the experience of musical listening, the nature of the virtual space it creates and the mental representations it evokes. At the end of the book, he adds a chapter that is in many ways underdetermined by the book's overall argument, in which he argues that the great interest we take in (Western, tonal) music derives from our horror of the merely contingent, our desire for an experience of transcendence and unity that is akin to religious experience. This chapter contains fascinating material on quite a few philosophers, including Kant, Hegel, Schopenhauer, Nietzsche, and Sartre -- all of whom supply arguments that harmonize with Nussbaum's contentions in a variety of ways. It also contains material on mystical experience that convinces one that the religion/music parallel Nussbaum investigates is real, and illuminating for at least some music..$^{40}$

39 Here I think Barshack (2008) is perceptive: "Affective intensity" (in Mozart) "does not result in a retreat from the play of variations and ambiguities which make up everyday existence.... In the height of passion, Mozart often invokes the frivolous and the commonplace."

40 Consider, however, the illuminating argument in Higgins $(1991,156)$, that music always promotes an attitude of receptivity, thus cultivating capacities to approach other people and the world in a "nondefensive, noncompetitive fashion". I am not sure that noncompetitive dispositions are always promoted, but her claim about the cultivation of receptivity is a powerful one, and to the extent that we accept it, we would have further reasons to doubt C. Nussbaum's claims about transcendence of the earthly. 
And yet. Why should we be so inclined to suppose that music offers one particular type of good to human life, rather than many types of good? C. Nussbaum is far too subtle to claim such a thing outright; ${ }^{41}$ but in his insistence on this one function of music, he at least suggests the primacy and centrality of this type of good. Like, and continuous with, philosophy, however, music would appear to assume different argumentative positions, seeing the world from different and contrasting points of view, in such a way that Steinberg's metaphor of "listening to reason" appears more apt than C. Nussbaum's idea of a single type of experience. (Indeed, religion itself contains many types of experience -- including the mystical impression of transcendence, but including, as well, the passion for earthly justice and the acceptance of an imperfection in earthly striving. ${ }^{42}$ )

I have tried to offer a reading of Mozart's opera that makes it plain that it offers a different sort of happiness, a happiness that is comic, uneven, uncertain, wary of grandiose claims of transcendence. Indeed, the music itself laughs up its sleeve at pretensions of that sort (as in those little muffled bursts of laughter in the Overture and in Venite, inginocchiatevi43). C. Nussbaum may well respond that opera, that impure mixed art form, which relies on real bodies and real sights, is not the musical medium that his argument (based on music's disembodied and invisible nature) addresses. Even the human voice itself appears an anomaly within the Nussbaum conception of a musical art without bounded spatiotemporal existence. All musical instruments refer in some way to the human body, but the voice, alone among the instruments, is a part of the body, and always expresses bodily frailty as well as potentiality. ${ }^{44}$

Just as there is a love that seeks transcendence and a love that repudiates that aspiration as immature and a precursor of disillusionment, so too, I think there are both sorts of music. It is no accident that Beethoven is on the cover of C. Nussbaum's book, ${ }^{45}$ and a major source of his musical examples. But the

41 Indeed, C. Nussbaum 2007, 286 he states that his intention is "to argue that the assuagement of the horror of the contingent came...to be one direct proper function (though by no means the only one) of the musical representations belonging to the musical style under consideration in this book. Ibid., 295 refers to the analysis in the chapter as dealing with "certain central cases" of musical emotion.

42 Indeed, l'd be inclined to say that C. Nussbaum's characterization of religious experience is more at home in Christianity than in Judaism, with its emphasis on the earthly nature of our ethical duties.

43 And if I am right about the allusion to venite adoremus, see above, the aria quite directly pokes fun at the search for transcendence.

44 Here a comment made by Mollie Stone, Assistant Conductor of the Chicago Children's Choir, is illuminating. Describing the contribution the Choir makes to the political and social development of children from a wide range of ethnic and racial backgrounds, she commented that the children become close to each other because they actually share their breath with one another, a kind of physical reciprocity that is much more intimate than anything that would be involved in orchestral performance (Interview, June 5, 2008). This comment fits well with the fine analysis of our physical engagement with music offered in Higgins 1991, especially 150-156.

45 A cover chosen by the author. 
yearning for the transcendent that is indeed embodied in Beethoven's version of the Enlightenment is first cousin to cynicism: realizing that the world embodied in the Ninth Symphony and Fidelio doesn't really exist, what can one do but make a sour face at the real world? ${ }^{46}$

If, however, one follows Mozart's version of Enlightenment politics, one will still see that the world as it is needs a great deal of work, and one will not stop aspiring to get that work done, making the world of the male voice somewhat more like the world of the female voice, with its commitment to fraternity, equality, and liberty. One will not stop seeking to educate young men to love music rather than the concerto of shells and cannons. One will, however, also at the same time embrace real people -- even men! -- as they are, and one won't stop loving them because they are (no doubt like oneself ${ }^{47}$ ) a mess. That, suggests the pause within the music, is a more hopeful direction, if not the only possible direction, for a workable conception of democratic political love.

46 As was done in a remarkable concert version of Fidelio directed by Daniel Barenboim in Chicago several years ago, in close connection to his political activism in the Middle East, in partnership with the late Edward Said. The added text by Said expressed the message that Fidelio just is unreal (just as unreal, Said suggests, as the idea of a decent Israel), and we should all be both angry and pessimistic about the world as it is.

47 Because, after all, as I've said, the representation of female reciprocity in the opera does not by any means imply that real-life women are free from narcissism and the urge to control others. 


\section{References}

Barshack, Lior 2008. The Sovereignty of Pleasure: Sexual and Political Freedom in the Operas of Mozart and Da Ponte. Law and Literature 20, 47-67.

Darnton, Robert 1997. The Forbidden Best-Sellers of Pre-Revolutionary France. New York: HarperCollins.

Cook, Malcolm (ed.) 1992, Beaumarchais: Le Mariage de Figaro. Bristol: Bristol Classical Press.

Herder, Johann Gottfried 2002. Philosophical Writings. Extr. and trans. Michael N. Forster. Cambridge: Cambridge University Press.

Higgins, Kathleen M., 1991. The Music of Our Lives. Philadelphia: Temple University Press.

Hunt , Lynn (ed.) 1993. The Invention of Pornography: Obscenity and the Origins of Modernity, 1500-1800. Cambridge: Zone Books.

Mozart, Wolfgang Amadeus 1993. Three Mozart Libretti. New York: Dover Publications. 1979. The Marriage of Figaro (Le Nozze di Figaro) in Full Score. New York: Dover Publications.

Nussbaum, Charles O. 2007. The Musical Representation: Meaning, Ontology, and Emotion. Cambridge, MA: MIT Press.

Nussbaum, Martha 2001. Upheavals of Thought: The Intelligence of Emotions. New York: Cambridge University Press.

------ 2008. Can There Be a "Purified Patriotism"?: An Argument From Global Justice. In Matthias Lutz-Bachmann ( ed.) volume on cosmopolitanism, forthcoming, Suhrkamp.

Rousseau, Jean-Jacques 1987 (1762). The Basic Political Writings. Trans. Donald A. Cress. Indianapolis: Hackett.

Solomon, Robert \& Kathleen Higgins 1991. The Philosophy of (Erotic) Love. Lawrence: University of Kansas Press.

Steinberg, Michael P. 2004. Listening to Reason: Culture, Subjectivity, and Nineteenth-Century Music. Princeton: Princeton University Press.

------ 2007. Judaism: Musical and Unmusical. Chicago: University of Chicago Press. 


\section{Appendix}

\section{Emotional Expression in Music: Upheavals of Thought}

For those unfamiliar with the approach to the expression of emotion in music that I defend in Upheavals of Thought (chapter 5), it seems worth summarizing briefly its main contentions. In the earlier chapters of the book, I defend a conception of emotions according to which they all involve intentional thought or perception directed at an object and some type of evaluative appraisal of that object made from the agent's own personal viewpoint, which ascribes significance to the object in terms of the agent's scheme of goals and ends. Thus, we do not grieve for every death in the world, but only for deaths of people who appear to us to be important in our lives; and so forth. These appraisals need not involve language or even complexity: I argue that most animals make at least some such appraisals of objects, and have emotions in consequence. All that is required is that they see the object (a bit of food, say) as good from the point of view of their own pursuits and goals.

I then investigate the role of non-cognitive components (feelings, bodily states) in emotions, and I argue that, although some such elements are likely to be present in most of our emotional experience, these non-cognitive elements do not have the constancy and regular association with the emotion type in question that would be required if we were to include them in the definition of an emotion of a particular type. Even with an emotion as simple as fear, which is indeed frequently associated with something like shivering or trembling, there are numerous counterexamples - including the very common case of the fear of death, which most of us have most of the time, in a way that has psychological reality and motivational power, but (usually) without any conscious awareness of trembling or shaking. With other more complex emotions, for example grief compassion, it is not easy even to begin to identify the bodily feelings that would belong to it. And often, even when we think we have identified such elements (grief feels like a pain in the stomach, say), we find, on closer inspection, that one may continue to have grief over time while these bodily manifestations change, often greatly. (A grieving person may sometimes feel achy, sometimes exhausted, sometimes endowed with extra energy: and yet it would be wrong to say that she is not still grieving.)

This general analysis is then complemented by an analysis (in chapter 3 ) of the ways in which social norms embodied in cultural traditions produce subtly different emotional repertories for actors in those traditions. Thus, anger is in a way a cultural universal, but specific forms of anger are very strongly shaped by social norms regarding what an insult is, what honor is, and so forth. This chapter is of obvious relevance for the account of Figaro given here. 
I then study (in chapter 4) the developmental character of emotions: the fact that our earliest emotional experiences date from a time at which we cannot use language and are unable, even, securely to identify objects and individuate them one from another. And those archaic patterns often persist into adult life, underneath the often sophisticated structure of adult love and grief.

I then turn to music, asking how we can best account for the fact - which seems evident to most listeners - that music embodies and expresses emotions. In other words, the fact that we say, with good reason, that this passage is joyful, this one expressive of deep grief, and so forth. We ascribe these emotional properties to music with great specificity, indeed with no less specificity than we would find possible when talking about poetry. (For example, we can talk about the specific type of love embodied in the Liebestod of Wagner's Tristan, and contrast it with the very different type of love embodied in Cherubino's Voi che sapete.) I point out that this question is not the same question as the question about the actual emotional experiences of the listener, since the listener might be distracted, or musically ignorant, etc. But, following the lead of Wayne Booth's illuminating analysis of literary response, I connect the expressive properties of the music with the experience of the "implied listener," meaning a listener who follows, knowledgeably, attentively, and appropriately, the musical experience mapped out in the work.

I now point out that philosophers have had difficulty explaining how music could embody anything like an emotion. On the one hand, some theorists (e.g. Eduard Hanslick) have said, correctly, that emotions embody evaluative thought - but they have not been able to see how music, being non-linguistic, could possibly embody such thought, so they have ended up denying that music can embody emotions. On the other hand, other theorists (e.g. Schopenhauer, Suzanne Langer) have started from the observation that music does indeed embody emotions, but agreeing with Hanslick that all thought is essentially linguistic in nature - they have concluded that emotions can't involve thought after all, but must be seen as stirrings or movements of the blood, without any intentionality or cognitive content.

The mistake made by both is to suppose that all thought is essentially linguistic in nature. By this point, l've already argued that both non-human animals and small children have many non-linguistic emotions, involving perceptions of what is salient for one's own well-being. What now needs to be added is the idea that these non-linguistic experiences need not be archaic or primitive; language does not hold a monopoly on cognitive sophistication. Once we see that a non-linguistic form of representation can contain as rich an array of possibilities as can language, we are ready to start thinking seriously about emotions in music.

Next, following the guidance of Mahler's letters, Proust's remarks on music, and Paul Hindemith's excellent book, A Composer's World, I argue that music differs 
from language in one important way: it is not the shopworn medium of our daily utilitarian communications, and thus it can often seem to have a superior power to illuminate the depths of the personality. In virtue of not being the language of habit, music possesses many properties in common with dreams.

I argue that the ways in which music expresses emotions are shaped by culture and by the history of a particular type of musical art-form, as well as, more specifically, by the particular composer's own expressive development. I am unable to hear music from a tradition unknown to me and to identify securely its emotional content. The "implied listener", then must be well educated in the specific musical tradition, including the composer's own way of expressing musical ideas. Thus, it is not possible to give an accurate account of a passage in a Mahler symphony, say, without being aware of how he typically uses the oboe, or the harp, and so forth.

Finally, I discuss the vexed question of the relationship between music and text, arguing that although a verbal text may give a definiteness of reference to music that it would otherwise lack, nonetheless the text often underdetermines the emotional trajectory of the music. Studying two songs from Mahler's Kindertotenlieder, I argue that the fact that these songs are about the deaths of two children is supplied by the txt; and yet, the precise nature of the grief they express (as to whether it is consoled by religion, or ultimately hopeless) is underdetermined by Rückert's text and is supplied by the music. This discussion is of obvious relevance to my account of Mozart and Da Ponte here. 